\title{
Why Context Matters for Educational Policy - Analysing Interactive Practice in the Governance of Education for Sustainable Development in Germany
}

\begin{abstract}
The implementation of global educational policies such as Education for Sustainable Development (ESD) entails different national strategies despite its international character. In Germany, the transfer of ESD is characterized by a multi-actor process including representatives from academia, administration, civil society organisations (CSOs), and educational practice - coordinated by the national state. On the basis of five focus group discussions, we examined how the individual actors coordinated their actions in this process. The results show that the communicative interactions of multi-actor processes mirror the specificity of the education sectors' structures and dynamics. In our analysis, we thus conclude that ESD governance is more than a question of national and regional structures: we argue that an understanding of the structures and cultures of the involved educational areas can contribute to a differentiated knowledge for future ESD policies.
\end{abstract}

Keywords: ESD, Educational Governance, coordination of action, context of educational policies

\section{Zusammenfassung}

Die Umsetzung globaler bildungspolitischer Programme wie Bildung für nachhaltige Entwicklung (BNE) unterscheidet sich im Vergleich nationaler Strategien. In Deutschland ist der Transfer von BNE durch einen staatlich koordinierten Multiakteursprozess mit Beteiligung von Verwaltungsvertreter/-innen, zivilgesellschaftlichen und bildungspraktischen Akteur/-innen, Wissenschaftler/-innen etc. gekennzeichnet. Basierend auf fünf Fokusgruppendiskussionen wurde die Handlungskoordination dieser Akteur/-innen untersucht. Die Ergebnisse zeigten, dass die interaktive Praxis der Akteur/-innen, die den Umsetzungsprozess von Policy Prozessen beeinflusst, stark durch bildungsbereichsspezifische Strukturen und Dynamiken geprägt ist. In unserer Analyse kommen wir so zu dem Schluss, dass BNEGovernance mehr ist als eine Frage nationaler oder regionaler
Strukturen: Es ist vielmehr ein Verständnis der Strukturen und Kulturen der einzelnen Bildungsbereiche, die ein Wissen für zukünftige Policy-Strategien der BNE-Verankerung beisteuern kann.

Schlüsselworte: BNE, Educational Governance, Handlungskoordination, Kontextualisierung von Bildungspolitik

\section{Educational Policies for ESD - an Introduction to ESD in Germany and the Perspective of Educational Governance}

International organisations such as the OECD and UNESCO are important drivers and agenda setters for educational policy agendas like ESD and Global Learning. UNESCO in particular has been striving to strengthen the efforts to implement ESD in all educational areas throughout the world. Recently it has launched its new program "ESD for 2030", which is oriented towards the international Agenda 2030 and its Sustainable Development Goals. Despite these broad international policy developments, there is a growing awareness that international policies do not simply "trickle down" to the national and regional levels to improve educational practice (Ball, Maguire, Braun, \& Hoskins, 2011). On the contrary, education policies are created, negotiated, and realized by networks of different actors between the international, national, and regional levels. To capture the complexity and the multi-faceted interdependencies, the governance perspective looks for coordination of action between the different stakeholders involved in a policy process (Abs, Brüsemeister, Schemmann, \& Wissinger, 2015).

This perspective is especially relevant in the field of ESD, where not only state actors are developing policies, but CSOs are playing an important role too. For this reason, there is a growing awareness in the literature on policy studies that implementing a specific strategy of ESD is always the result of a "historically contingent balance between national and regional governments and NGOs” (Læssøe \& Mochizuki, 2015, p. 32). 
Although efforts to strengthen ESD are fostered by international organisations on the level of legitimation and agenda-setting, it is often the local context with its contextualised practices and policies that matters (Kolleck, Jörgens, \& Well, 2017). In Germany, this context of ESD is influenced by a long tradition of Environmental Education, Global Learning, and ESD - educational concepts that have been pushed by civil society actors and engaged researchers since the 1970s. In the last years, state actors have been taking over more responsibility and at the same time, negotiations between state actors and non-state actors have evolved. Especially during the UN Decade, the intensive coordination of action between different actors resulted in a situation in which the ESD governance regime was characterised by hybrid constellations and dynamic processes (Bormann \& Nikel, 2017).

With the launch of the UNESCO Global Action Programme (GAP, 2014-2019), the Federal Ministry of Education and Research (BMBF) took over the coordination of a huge multi-stakeholder process, which is still ongoing in the current program. The ministry created different bodies (National Platform, six Expert Forums, and Partner Networks) to transfer ESD into all educational structures. The process was and still is structured in line with the different educational areas - early childhood education, school education, vocational education and training, higher education, non-formal/informal learning and learning in local authorities. A National Action Plan to further implement ESD was formulated and adopted in 2017 (National Platform on Education for Sustainable Development 2017). Nevertheless, if this policy strategy is not going to simply trickle down from the national level into the structures of the different educational areas, the question is how the social innovation of ESD (Bormann 2013) is adapted in the different educational areas. A recent study has shown that the transfer of ESD takes place along different paths of transformation, where the social innovation ESD influenced the structures of the different educational areas and, vice versa, the performative logics of the different educational areas affected the specific discussions about ESD (Singer-Brodowski, Etzkorn, \& Seggern, 2019). With the aim of better understanding the respective modes of governance that are deeply interwoven with these paths of transformation, we conducted a study focusing on the governance of ESD in each educational area.

\section{Research Interest and Methodology}

The objective of the original study on which this article is based was to reconstruct the coordination of action ${ }^{1}$ of the actors involved in the various bodies of the GAP following the respective educational areas (early childhood education, school, vocational training, higher education, non-formal/informal learning, local authorities) (Singer-Brodowski, Seggern, Duveneck, \& Etzkorn 2020). In this article, we present an in-depth analysis that focuses primarily on the implicit aspects of the coordination of action within the different educational areas and how the actors referred to each other. Such an analysis can clarify the dynamics of the educational sectors and contribute knowledge for a stronger transfer of ESD.

Focus group discussions were chosen for data collection to capture the interaction dynamics as a source of knowledge
(Flick, 2018) that do not exist in isolation, but rather arise precisely within social exchange. This focus assumed that the participants in the discussions not only exchanged individual opinions, but also acted communicatively due to their respective organisational backgrounds. For this reason, the coordination of action in the focus groups is to be understood similar to the communication within the bodies of the GAP, since they follow the same structural logic. ${ }^{2}$ Four to seven representatives of academia, administration, civil society, and educational practice were invited to form a focus group (33 persons in total). Most of them were members of the GAP bodies. The data analysis was carried out throughout a thematic qualitative text analysis (Kuckartz, 2014).

On the one hand, our original analysis focused on the arguments that were explicitly exchanged between the experts. On the other hand, shifting to the focus of this article, it concentrated on the mode of coordinating action in situ - the implicit way of communicative interaction that was realized in the educational area-specific discussions (Bohnsack, 2018). ${ }^{3}$ Based on Bohnsack, we understand the interaction within the focus group discussions as an argumentative expression of conjunctive practice $(2018$, p. 201f.). In this sense, we attempted to better understand "the interactive practice of the professional actors with their clientele of (predominantly) implicit normative orientations or values" ${ }^{\prime \prime}$ (Bohnsack, 2020, p. 8) by analysing their reference to each other. This considered the way they spoke to each other, interruptions or voicing agreement and support, and turn-taking. We extended Bohnsack's concept of interactive practice beyond his usage (Bohnsack 2020) for professionals in pedagogical practice to actors from academia, administration, and civil society. In investigating how the actors interacted with each other, we focus on the performative logic of the practice (ibid., p. 211) within the implementation of ESD governance. In the following we first present the results of the synthesis of the interactive practice for the respective educational areas and then classify these interpretatively.

\section{Findings and Discussions: Interactive Practice within the Focus Group Discussi- ons of the Different Educational Areas}

Early Childhood Education: The interaction in this focus group discussion was mainly characterized by agreement between the participants, who expressed appreciation for and joy in the interest and work of the others. These aspects showed a high level of cooperation between the participants in the discussion as well as a consensus-oriented search for solutions to implement ESD in early childhood education. Representatives of academia and the state administration showed the largest share of speech in the discussion. Both agreed with the other participants and actively took up their arguments. Especially the representative of academia rejected the political legitimation of the representatives of the national and federal administration, although this was expressed in a humorous way.

The interactive practice within the discussion was strongly oriented towards a norm-setting academia. This norm-setting role of academia is also indicative of the importance of scientific expertise in the social and political upgrading of early childhood education in recent years. As a result of the 
PISA studies and various other factors such as the shortage of skilled workers and the associated efforts to improve the compatibility of family and career, the importance of early childhood education has increased enormously (Anders, 2018). This process of professionalisation has mainly been driven by researchers, who have called for a paradigm shift focusing on the child's perspective and participation in the educational organisations. In Germany, the governance of early childhood education is based on a corporatist minimalist steering model (Ratermann \& Stöbe-Blossey, 2012, p. 15) which has its historical roots in the autonomy and plurality of the day care centres. With the social and political upgrading of early childhood education, state organisations have started to influence early childhood education more proactively - for example in the context of quality development by formulating educational plans on the federal level (ibid.). Nevertheless, the dominant pattern of professionalization in the focus group discussion on early childhood ESD mirrors an interactive practice that is influenced more by academia than by state institutions.

School: The participants in the focus group discussion made (critical) references to each other: differences were corrected, questioned, and discussed. The participants varied greatly in their turn-taking: while the representatives of the state administration and academia spoke for above average lengths of time, the person from educational practice expressed him/ herself very little. Nevertheless, the representative of educational practice was questioned in particular by the other participants, and his/her (few) contributions were also interrupted and continued by other discussants - in contrast to the contributions of other participants. The representatives of the state administration asked questions, tried to create consensus between the others, and moderated the discussion. The representatives of the state administration thus provided opportunities for statements of others on the one hand, but at the same time dominated the turn-taking and therefore partly steered the discussion. Although the representatives of civil society mostly disagreed with representatives of the state administration, they also built on the latter's arguments.

The interactive practice of the actors can be differentiated analytically using the perspective of educational governance: historically, since the 1980s reforms in Germany have given schools more scope to shape educational content (Altrichter 2015). However, these reforms were accompanied by the introduction of performance standards and comparisons (PISA, etc.) (Altrichter, 2015, 2017). Schools in Germany thus became more autonomous in terms of content while learning outcomes became more regulated. For this reason, in practice, individual schools rarely noticed a great change in the freedom to shape educational content (ibid.). This field of tension is reflected in the ambivalence of creating possibilities for speech contributions, simultaneous implicit steering of the discussion and non-integration of educational practice by the representatives of the state administration. We further interpret the questioning interactive practice as indicative of increasing competition for resources in the school education sector: schools increasingly follow a logic of "regulation and performance" (Altrichter 2015, p. 26) developed from reforms and compete in the process. Additionally, CSOs as new, non-formal educational actors became more important: Altrichter displays how opportunities for acting can change during reform phases and how "new actors" can appear (ibid., p. 35). In this sense, we understand civil society as a new actor whose importance in the cooperation of schools with non-formal educational organisations increases but is mainly limited to this cooperation instead of independent engagement (Singer-Brodowski, 2019).

Vocational Education and Training (VET): The focus group discussion was characterized by a complementary interaction expressed in the argumentative connection to other statements. The representative of academia in particular tried to develop an exchange with the representatives of educational practice and the federal administration. Within this process one main disagreement arose because the member of academia pointed out the contradictions, tensions and conflicting goals in the process of integrating ambitious and transformative demands of sustainability in economy and VET. In contrast to this position, a representative of educational practice concentrated on the concrete and more incremental action orientation of VET and also saw the goal of ESD in an inclusive education for democracy. The person argued that in the background of increasingly polarized debates on sustainability - for example about policies against climate change - the aim of VET should be to enable trainees to socially engage in democratic processes instead of reflecting abstractly on conflicting aims.

The interactive practice in the discussion on VET becomes more understandable against the background of a fundamental tension in VET between abstract ethical demands and individual action orientation for vocational employability. On the one hand, ideally, ESD should discuss ethical ambitions and use conflicting aims as a starting point for deep learning by the apprentices (Vollmer \& Kuhlmeier, 2014, p. 201). On the other hand, with this aim ESD provokes individual educational processes for sustainable development that do not directly contribute to employability. These aspects are deeply interwoven with the dual structure of VET in Germany, where a fundamental "contradiction between an orientation towards in-company usability and an orientation towards educational goals of the school system" (Clement 2015, p. 29) exists. The governance of VET in Germany is shaped by a corporatist distribution of jurisdictions between administrations, employers' and employees' associations (ibid.). They are involved in all relevant committees and must negotiate pivotal decisions until consensus is reached. For this reason, "decisive steering functions within the dual system are performed by private-sector associations" (Clement, 2007, p. 208). This division of labour and the accompanying culture of consensus-oriented negotiation was expressed in the complementary argumentation of the actor in the focus group, with the sole exception of the special role of the representative of academia.

Higher Education: The participants of this focus group debated how ESD could be strategically integrated into higher education in a meaningful way. To this end, they discussed ESD exclusively in terms of sustainability; didactical aspects of ESD were not addressed. The following ambivalence was noticeable in the interaction: On the one hand, the representatives of educational practice and civil society turned to the representative of academia for an assessment and asked for his/ her opinion. On the other hand, they repeatedly disagreed with this person. While the representative of academia stressed that ad- 
ministration only implements content for higher education institutions but is not involved in creating it, the representative of administration went on to agree to that throughout the discussion. The representative of academia took up by far the largest share of speech.

We link the interactive practice in the discussion to the educational governance of higher education in the following way: the high degree of autonomy of universities that defines governance of higher education's institutions in Germany is also reflected in the generation of scientific knowledge, which is just as difficult to steer as the institution of higher education itself (Gläser \& Lange, 2007, p. 441). The creation of new knowledge follows a non-regulable momentum which is rarely calculable even from within scientific communities (ibid.). The representatives of educational practice and civil society "labour" on this poorly controllable momentum of academia, which was mirrored in the sovereignty of speech that the representative of academia showed during the discussion. The establishment of the autonomy of institutions of higher education can be understood as a deeply rooted quality criterium and logic of academia, in the generation of intersubjective validated insights and truths (Schimank, 2012, p. 114), which was expressed in the interactive practice of the academic representative. We further interpret that the participants also almost exclusively discussed ESD on the basis of sustainability because this broad topic can be linked most easily to higher education policies and funding interests and thus pays off for the content-related autonomy of higher education institutions: in higher education institutions and its management, sustainability is the most frequently used profiling topic and an ideal term for docking onto interdisciplinarity in its complexity of content (Stuckrad, Röwert, Berthold, \& Müller, 2017).

Non-Formal Education: In comparison to the other discussions, a relatively balanced share of speech was evident. Overall, the actors showed understanding for the other perspectives and searched for common ground, but also disagreed with each other in terms of content, which was expressed in a "yes and no" argumentation. It was characterised by the search for cooperation with each other and tendencies for demarcation from each other at the same time (symbiotically and suspensefully). Particularly between representatives of state organisations and CSOs, there were several frictions throughout the discussion about participation claims and realities as well as the transparency of policies.

The interpretation of the focus group discussion reveals the permanent demarcation and simultaneous symbiosis between non-state and state actors (Altrichter \& Heinrich, 2007, p. 68). On the one hand, state actors are dependent on civil society activities (and their expertise) to implement ESD. On the other hand, many civil society activities for ESD can only be implemented if (additional) state funding is made available. In the coordination of action in the non-formal education sector, two very different modes of governance come together in comparison with the other education sectors: a steering logic of the state that tends to be hierarchical and a grassroots self-management of civil society (Altrichter, 2015). Historically, civil society actors have played a great part in lobbying for more ESD in formal education and initiated a broad range of non-formal educational practices (Singer-Brodowski, 2019, p. 302). At the same time, the claim to bring ESD from project to structure (German Commission for UNESCO, 2013) is associated with an ambivalent - if not insolvable - task for non-formal and civil society-oriented educational organisations. On the one hand, they want to have an even greater impact through stronger activities and can, therefore, welcome a structural implementation of ESD in the formal education sector; on the other hand, the formal structure increasingly dominates their educational work. This ambivalence was also expressed in the yes and no argumentation during the focus group.

\section{Conclusion}

To transfer a global innovation such as ESD into a national context, it is necessary to gain a deeper understanding of the respective structures, their particularities, and their effects on the coordination of action of the actors involved, since these aspects influence the context of transfer. For Germany, our results show a divergent coordination of actions and interactive practice between the educational areas, ranging from a cooperative problem-solving orientation (early education) and an implicit steering of the administration (school), to the complementary logic and the strong influence of a market-based training environment that avoids addressing ethical contradictions (VET) and the struggle to influence the autonomous higher education institutions actors (higher education), to a concurrent symbiotic and demarcating coordination of action in the field of non-formal education institutions.

We argue that a contextualized perspective of the policy processes of global education programs such as ESD requires more than consideration of national or local particularities. It is also a question of how the interactive space of experience is acted upon in the different educational areas, since this performance hides information about how actors negotiate on the structural context and the cultures that shape their actions. Nevertheless, the shapes of the communicative interactions cannot be limited to the structural context. Based on the scientific discourses about the relevance of local contexts and the consideration of historical developments, we added attempts to specify them through our results, be it the national context, which in Germany is reinforced by the specificity of a federal system, or the context of the educational policy frameworks of the respective educational areas. For Germany's ESD governance, the logic of the individual educational sectors could be understood as an important influence on the interactive practices that shape multi-stakeholder-processes and thus the implementation process of ESD itself.

The educational area-specific negotiations and performative logics that were reconstructed within the five focus group discussions could also be of interest to other countries with educational areas that have undergone similar historical development. In this sense, this analysis improves an understanding of education sector specificity as a crucial criterion of contextualisation for policy transfers. It is therefore not enough to aim for a transfer of policies from one national context to another; rather, it is necessary to consider the historically and socially constructed contexts of the environment of transfer about which the conjunctive practice provides information. 


\section{Notes}

1 Coordination of actions refers to the mutual adjustment of actions and negotiation of interdependencies among the various actors involved in regulating collective issues within multi-actor policy processes.

2 As a result of the common practice of acting and negotiating suitable strategies to implement ESD, the focus group discussions can be understood as conjunctive spaces of experience (Bohnsack 2018, p. 206)

3 Our methodical analysis was inspired by the documentary method but not systematically applied as such. See Singer-Brodowski et al. 2020 for a thorough discussion of the methodical implementation and limitations of the study.

4 Originally German quotations were translated into English by the authors.

\section{References}

Abs, H. J., Brüsemeister, T., Schemmann, M., \& Wissinger, J. (eds.) (2015). Educational Governance: Vol. 26. Governance im Bildungssystem: Analysen zur Mehrebenenperspektive, Steuerung und Koordination. Wiesbaden: Springer VS. https://doi.org/1 0.1007/978-3-658-06523-2.

Altrichter, H. (2015). Theory and Evidence on Governance: Conceptual and Empirical Strategies of Research on Governance in Education. In J. Schrader, J. Schmid, K. Amos, \& A. Thiel (eds.), Governance von Bildung im Wandel (pp. 25-43). Wiesbaden: Springer Fachmedien Wiesbaden. https://doi.org/10.1007/978-3-658-0727 $0-4 \_2$.

Altrichter, H., \& Heinrich, M. (2007). Kategorien der Governance-Analyse und Transformationen der Systemsteuerung in Österreich. In H. Altrichter, T. Brüsemeister, \& J. Wissinger (eds.), Educational Governance: Vol. 1. Educational Governance: Handlungskoordination und Steuerung im Bildungssystem (pp. 55-103). Wiesbaden: VS Verlag für Sozialwissenschaften. https://doi.org/10.1007/978-3-531-90498-6_ 3 .

Anders, Y. (2018). Professionalität und Professionalisierung in der frühkindlichen Bildung. Zeitschrift Für Grundschulforschung, 11(2), 183-197. https://doi.org/10.10 07/s42278-018-0031-3.

Ball, S. J., Maguire, M., Braun, A., \& Hoskins, K. (2011). Policy Subjects and Policy Actors in Schools: Some Necessary but Insufficient Analyses. Discourse: Studies in the Cultural Politics of Education, 32(4), 611-624. https://doi.org/10.1080/015963 06.2011.601564.

Bohnsack, R. (2018). Praxeological Sociology of Knowledge and Documentary Method: Karl Mannheim's Framing of Empirical Research. In M. Kettler \& V. David (eds.), Anthem companions to sociology. The Anthem companion to Karl Mannheim (pp. 199-220). London: Anthem Press.

Bohnsack, R. (2020). Professionalisierung in praxeologischer Perspektive: Zur Eigenlogik der Praxis in Lehramt, sozialer Arbeit und Frühpädagogik. Erziehungswissenschaft, Soziologie, Soziale Arbeit. Opladen: Verlag Barbara Budrich.

Bormann I. (2013). Bildung für nachhaltige Entwicklung als Praxis sozialer Innovation. In J. Rückert-John (eds.), Soziale Innovation und Nachhaltigkeit. Innovation und Gesellschaft (pp. 269-288). Wiesbaden: VS Verlag für Sozialwissenschaften. https://doi.org/10.1007/978-3-531-18974-1_14

Bormann, I., \& Nikel, J. (2017). How Education for Sustainable Development Is Implemented in Germany: Looking Through the Lens of Educational Governance Theory. International Review ofEducation, 63(17), 793-809. https://doi.org/10.1007 /s11159-017-9683-9.

Clement, U. (2007). Educational Governance an der Schnittstelle sozialer Systeme - Das Beispiel der beruflichen Bildung. In H. Altrichter, T. Brüsemeister, \& J. Wissinger (eds.), Educational Governance: Vol. 1. Educational Governance: Handlungskoordination und Steuerung im Bildungssystem (Vol. 73, pp. 207-230). Wiesbaden: VS Verlag für Sozialwissenschaften. https://doi.org/10.1007/978-3-531-9049 8-6_8.

Clement, U. (2015). Politische Steuerungslogiken beruflicher Bildung. Zentrifugale und zentripetale Kräfte in der Governance beruflicher Bildung. In S. Bohlinger \& A. Fischer (eds.), Lehrbuch europäische Berufsbildungspolitik: Grundlagen, Herausforderungen und Perspektiven (pp. 25-55). Bielefeld: Bertelsmann, W. Retrieved from https://www.pedocs.de/volltexte/2016/11632/pdf/Clement_2015_Steuerungslogiken.pdf.

Flick, U. (ed.) (2018). The SAGE Handbook of Qualitative Data Collection. Los Angeles, London, New Delhi, Singapore, Wahington DC, Melbourne: SAGE reference.

German Commission for UNESCO (2013). The German National Committee for the UN Decade of Education for Sustainable Development. Position paper "Strategy for ESD 2015+". Bonn.

Gläser, J., \& Lange, S. (2007). Wissenschaft. In A. Benz, S. Lütz, U. Schimank, \& G. Simonis (eds.), Handbuch Governance: Theoretische Grundlagen und empirische Anwendungsfelder (pp. 437-451). Wiesbaden: VS Verlag für Sozialwissenschaften. https://doi.org/10.1007/978-3-531-90407-8_33.
Kolleck, N., Jörgens, H., \& Well, M. (2017). Levels of Governance in Policy Innovation Cycles in Community Education: The Cases of Education for Sustainable Development and Climate Change Education. Sustainability, 9(11), 1966. https://d oi.org/10.3390/su9111966.

Kuckartz, U. (2014). Qualitative Text Analysis: A Guide to Methods, Practice \& Using Software (A. Mcwhertor, Trans.). Los Angeles: SAGE. Retrieved from http://lib.myili brary.com/detail.asp?id=617246

Læssøe, J., \& Mochizuki, Y. (2015). Recent Trends in National Policy on Education for Sustainable Development and Climate Change Education. Journal of Education forSustainableDevelopment, 9(1),27-43.https://doi.org/10.1177/09734082155691 12.

National Platform on Education for Sustainable Development (2017). National Action Plan on Education for Sustainable Development. The German contribution to the UNESCO Global Action Programme. Retrieved from: https://www.bne-portal. $\mathrm{de} / \mathrm{sites} / \mathrm{def}$ ault/files/downloads/publikationen/BMBF_NAP_BNE_EN_ Screen_2.pdf.

Ratermann, M., \& Stöbe-Blossey, S. (eds.) (2012). Governance von Schul- und Elementarbildung. Wiesbaden: VS Verlag für Sozialwissenschaften. https://doi.org/10.1 007/978-3-531-94241-4.

Schimank, U. (2012). Wissenschaft als gesellschaftliches Teilsystem. In S. Maasen, M. Kaiser, M. Reinhart, \& B. Sutter (eds.), Handbuch Wissenschaftssoziologie (pp. 113-123). Wiesbaden: Springer.

Singer-Brodowski, M. (2019). Bildung für nachhaltige Entwicklung im Bereich des non-formalen und informellen Lernens. In M. Singer-Brodowski, N. Etzkorn, \& T. Grapentin-Rimek (eds.), Schriftenreihe "Ökologie und Erziehungswissenschaft" der Kommission Bildung für eine nachhaltige Entwicklung der Deutschen Gesellschaft für Erziehungswissenschaft (DGfE). Pfade der Transformation: Die Verbreitung von Bildung für nachhaltige Entwicklung im deutschen Bildungssystem (pp. 291-348). Leverkusen: Verlag Barbara Budrich.

Singer-Brodowski, M., Etzkorn, N., \& Seggern, J. von (2019). One Transformation Path Does Not Fit All-Insights into the Diffusion Processes of Education for Sustainable Development in Different Educational Areas in Germany. Sustainability, 11(269). https://doi.org/10.3390/su11010269.

Singer-Brodowski, M., Seggern, J. von, Duveneck, A., \& Etzkorn, N. (2020). Moving (Reflexively within) Structures. The Governance of Education for Sustainable Development in Germany. Sustainability, 12(7), 2778. https://doi.org/10.3390/su1 2072778.

Stuckrad, T. von, Röwert, R., Berthold, C., \& Müller, U. (2017). Themenfelder als Profilbildungselement an deutschen Hochschulen: Trendanalyse und Themenlandkarte. Gütersloh: Centrum für Hochschulentwicklung.

Vollmer, T., \& Kuhlmeier, W. (2014). Strukturelle und curriculare Verankerung der Berufsbildung für nachhaltige Entwicklung. In W. Kuhlmeier, A. Mohorič, \& T. Vollmer (eds.), Berichte zur beruflichen Bildung. Berufsbildung für nachhaltige Entwicklung: Modellversuche 2010-2013; Erkenntnisse, Schlussfolgerungen und Ausblicke (pp. 197-223). Bielefeld: Bertelsmann Verlag GmbH \& Co. KG.

\section{Janne von Seggern}

has been working in the national monitoring of ESD at the Freie University Berlin since 2017. She has been involved in intercultural youth work for eight years, both on a voluntary basis and as part of her training as a social and cultural anthropologist. Her research focuses on ESD, environmental anthropology and international cooperation.

\section{Dr. Mandy Singer-Brodowski}

wrote her PhD on Higher Education for Sustainable Development at the Leuphana University of Lüneburg and worked on questions of transformative science at the Wuppertal Institute of Climate, Environment and Energy. Since 2016, she has coordinated the Monitoring of ESD in Germany. Her research interests are transformative learning and ESD. 